\section{A NOTE ON THE OCCURRENCE OF CUCUMIS SATIVUS L. FORMA HARDWICKII (ROYLE) W.J. DE WILDE \& DUYFJes (CUCURBITACEAE) IN PENINSULAR INDIA}

\author{
Mandar N. Datar ${ }^{1}$, Girish Pathak ${ }^{2}$ \& Hemant V. Ghate ${ }^{3}$ \\ ${ }^{1}$ Scientist B, Agharkar Research Institute, GG Agarkar Road, Pune, \\ Maharashtra 411004, India \\ ${ }^{2}$ MSc (Biodiversity) Student of A. Garware College, Pune, Maharashtra \\ 411 004, India \\ ${ }^{3}$ Department of Zoology, Modern College, Shivajinagar, Pune, \\ Maharashtra 411005, India \\ ${ }^{1}$ datarmandar@gmail.com, ${ }^{2}$ pathak.giri172@gmail.com, \\ ${ }^{3}$ hemantghate@gmail.com (corresponding author)
}

The genus Cucumis L. (Cucurbitaceae) is distributed in the tropical region with about 52 species (Mabberley 2008). This genus is of horticultural importance as it has many cultivated species with a large diversity of wild germplasm. There are six species in India (Chakravarty 1982), of which Cucumis sativus L. (Cucumber) is cultivated widely for its edible fruits. Additionally, one wild variant of Cucumis sativus is also found to grow in wild, which was collected during our routine field work in Tikona Fort area of Pune District (Image 1). This wild form was compared with cultivated form of Cucumis sativus L. for morphological characters.

The differences between these wild growing plants and cultivated ones are quite significant and are given in Table 1. To understand the distribution of this wild form, specimens deposited in Herbarium of Botanical Survey of India, Western Regional Centre (BSI), Pune were scrutinized. The scrutiny revealed that this wild form of Cucumis sativus L. occurs widely throughout peninsular India.

In many Indian floras, this wild population of cucumber is treated only under Cucumis sativus L. But from the above characteristics it appears to be unjustified to keep the wild as well as cultivated populations under a single species.

This issue has been discussed by various authors (Duthie 1903; Kirkbride 1993; Jeffrey 2001; de Wilde \& Duyfjes 2010). Most of them have treated the cultivated form as Cucumis sativus L. var. sativus and the wildly occurring form as Cucumis sativus L. var. hardwickii (Royle) Alef. The latter was originally described as a distinct species by Royle (1835) as C. hardwickii Royle. Duthie (1903) considered Cucumis sativus var. hardwickii (Royle) Alef. just as the wild form of the cultivated cucumber, as both have all essential characteristics in common. De Candolle considered C. hardwickii Royle as a weedy form of $C$. sativus that escaped from cultivation, rather than assuming it as the ancestor of this species (de Wilde \& Duyfjes 2010). Kirkbride (1993), while describing Cucumis sativus L., added a note for this distinct form stating "smaller, more delicate plants with bitter fruits have traditionally been identified as C. sativus var. hardwickii". Jeffrey (2001), in support of Kirkbride (1993), stated that typical members of the var. hardwickii can be easily identified but that no morphological characteristics clearly separate it.

It is quite clear from the above discussion, that the taxa occurring in the wild should be treated separately from the cultivated one. Some authors have treated it

DOI: http://dx.doi.org/10.11609/JoTT.03415.5010-2

Editor: P. Lakshminarasimhan, Botanical Survey of India, Howrah, India.

Date of publication: 26 November 2013 (online \& print)

Manuscript details: Ms \# 03415 | Received 21 November 2012 | Final received 21 July 2013 | Finally accepted 19 October 2013

Citation: Datar, M.N., G. Pathak \& H.V. Ghate (2013). A note on the occurrence of Cucumis sativus L. forma hardwickii (Royle) W.J. De Wilde \& Duyfjes (Cucurbitaceae) in peninsular India. Journal of Threatened Taxa 5(15): 5010-5012; http://dx.doi.org/10.11609/JoTT.03415.5010-2

Copyright: (c) Datar et al. 2013. Creative Commons Attribution 3.0 Unported License. JoTT allows unrestricted use of this article in any medium, reproduction and distribution by providing adequate credit to the authors and the source of publication.

Funding: None.

Competing Interest: The authors declare no competing interests.

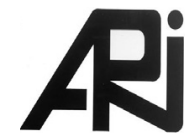

Acknowledgements: We sincerely thank Willem de Wilde and Brigitta Duyfjes (Netherlands Center for Biodiversity Naturalis / Naturalis Biodiversity Center, Leiden University, Leiden, The Netherlands) for their valuable help in settling the identity of this plant on the basis of pictures sent to them. We also thank them for critically commenting on the first draft of this short note. We also thank the Director, Agharkar Research Institute, Pune and authorities of Modern College, Pune for facilities and encouragements. We are also thankful to In-charge, BSI, Pune for allowing us to consult the herbarium. 

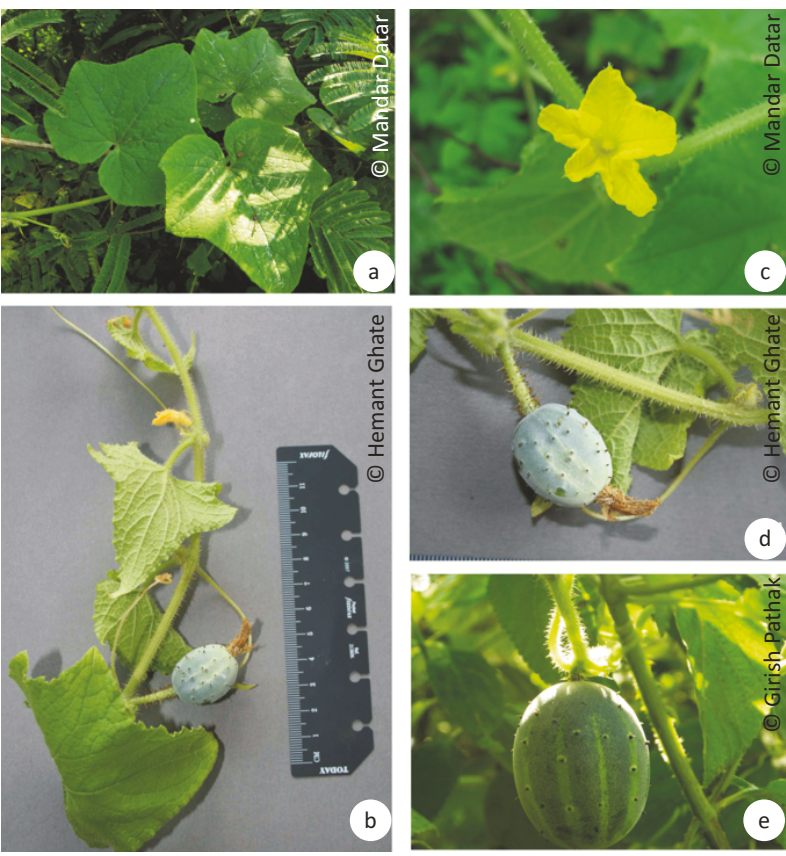

Image 1. Cucumis sativus L. forma hardwickii (Royle) W.J. De Wilde \& Duyfjes

a - leaves; b - twing with flower and fruits; c - flower; $d$ - immature fruit; e - mature fruit.

as C. sativus forma hardwickii (de Wilde \& Duyfjes 2010) while some have treated it as a variety, i.g., C. sativus var. hardwickii. Kirkbride (1993) in his monograph placed four species and one variety of Cucumis from South East Asia in the synonymy of $C$. sativus, viz. $C$. hardwickii Royle, $C$. muricatus Willd., C. rumphii Hassk., C. setosus Cogn. and C. sativus L. var. sikkimensis Hook. $f$. This synonymy was partly accepted by de Wilde \& Duyfjes (2007) except for C. hardwickii which they retained as the separate wild variety. But recent detailed studies by the same authors (de Wilde \& Duyfjes 2010) have resulted in the wild form being treated as $C$. sativus forma hardwickii (Royle) W.J. de Wilde \& Duyfjes and not as a separate variety.

This wild form has not been reported in earlier major floras on peninsular India as the authors treated it only in Cucumis sativus L. (Matthew 1983; Saldanha 1984; Sharma et al. 1984; Rao 1985; Pullaiah 1997; Almeida, 1998; Rao 2001). But Jeffrey (2001) described the distribution of this forma hardwickii from peninsular India to Sri Lanka. In addition to wild and cultivated forms, there are some forms found as an escape from cultivation. We, therefore, suggest that these escaped forms along with cultivated ones need to be treated under Cucumis sativus L. proper while the wild population occurring in peninsular India is to be treated as $C$. sativus forma hardwickii (Royle) W.J. de Wilde \& Duyfjes (Image
Table 1. Differences between cultivated and wild forms of Cucumis sativus L.

\begin{tabular}{|l|l|l|}
\hline Character & $\begin{array}{l}\text { Cultivated form of } \\
\text { Cucumis sativus }\end{array}$ & $\begin{array}{l}\text { Wild form of Cucumis } \\
\text { sativus }\end{array}$ \\
\hline Inflorescence & Many flowered & $1-3$ flowered \\
\hline Fruiting season & $\begin{array}{l}\text { Almost throughout the } \\
\text { year }\end{array}$ & $\begin{array}{l}\text { September to January. On } \\
\text { many occasions fruits are } \\
\text { seen even on dried plants }\end{array}$ \\
\hline Fruit shape & Ellipsoid or cylindrical & Ovoid to slightly ellipsoid \\
\hline Fruit color & $\begin{array}{l}\text { Yellowish-green without } \\
\text { stripes }\end{array}$ & Green with white stripes \\
\hline Fruit surface & $\begin{array}{l}\text { Less scabrid, more or less } \\
\text { smooth }\end{array}$ & $\begin{array}{l}\text { Scabrid, with deciduous } \\
\text { spine like structures on } \\
\text { the surface }\end{array}$ \\
\hline Fruit Taste & Neutral, not bitter & Bitter \\
\hline Seed length & $7-11 \mathrm{~mm}$ long & $6-7$ mm long \\
\hline
\end{tabular}

1) and not under C. sativus. A good description and illustration of $C$. sativus forma hardwickii (Royle) W.J. de Wilde \& Duyfjes are provided by the authors (de Wilde \& Duyfjes 2010).

Specimens studied: Dadra-Nagar Haveli: 127095A (BSI), 14.xi.1970, Sindhoni Forest, Nagar Haveli, coll. M. Y. Ansari.

Karnataka: 73565(BSI), 04.ix.1961, Katedevargudi, Mysore District, coll. R.S. Rao.

Kerala: 62279 (BSI), 20.vi.1960, Hereford Estate, coll. K.C. Kanodia.

Maharashtra: 101065 (BSI), 28.x.1964, Ambavane, District Pune, coll. B.V. Reddi; 111329 (BSI), 12.ix.1967, Peint, District Nasik, John Cherian; 27429 \& 27430 (AHMA) (Images 2 \& 3), 20.ix.2011, Tikona Fort, Taluka Maval, District Pune, coll. M.N. Datar; 99196 (BSI), 26.ix.1964, near Valvan Dam, District Pune, coll. B. V. Reddi.

\section{REFERENCES}

Almeida, M.R. (1998). Flora of Maharashtra - Vol. II. Blatter Herbarium, Mumbai, 316pp.

Chakravarty, H.L. (1982). Fascicles of Flora of India. Fascicle 11. Cucurbitaceae. Botanical Survey of India, Howrah, 73 pp.

de Wilde, J.J.O. Willem \& B.E.E. Duyfjes (2007). The wild species of Cucumis L. (Cucurbitaceae) in South-East Asia. Adansonia. 29(2): 239-248.

de Wilde, J.J.O. Willem \& B.E.E. Duyfjes (2010). Cucumis sativus L. forma hardwickii (Royle) W. J. de Wilde \& Duyfjes and feral forma sativus. Thai Forest Bulletin (Bot) 38: 98-107.

Duthie, J.F. (1903). Flora of the Upper Gangetic plain and of the adjacent Siwalik and sub-Himalayan tracts. Calcutta 374pp.

Jeffrey, C. (2001). Cucurbitaceae. In: P. Hanelt (ed.), Mansfeld's Encyclopedia of Agricultural and Horticultural Crops. Springer verlag, Berlin, Heidelberg. 3: 1510-1557.

Kirkbride, J.H. (1993). Biosystematic monograph of the genus Cucumis (Cucurbitaceae). Parkway publishers, Boone, North Carolina, 159pp. Mabberley, D.J. (2008). Mabberley's Plant Book A portable dictionary 


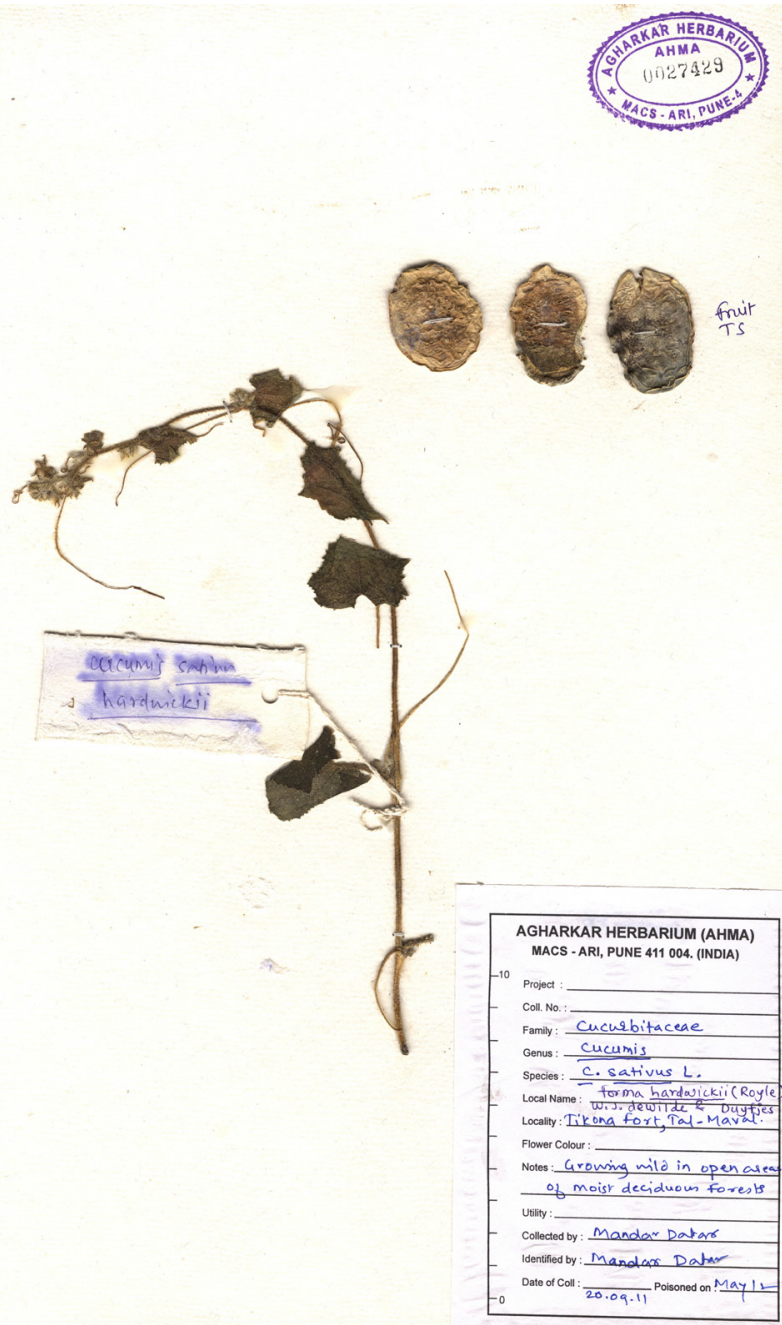

Image 2. Herbarium sheet of Cucumis sativus I. forma hardwickii (Royle) (27429 AHMA)

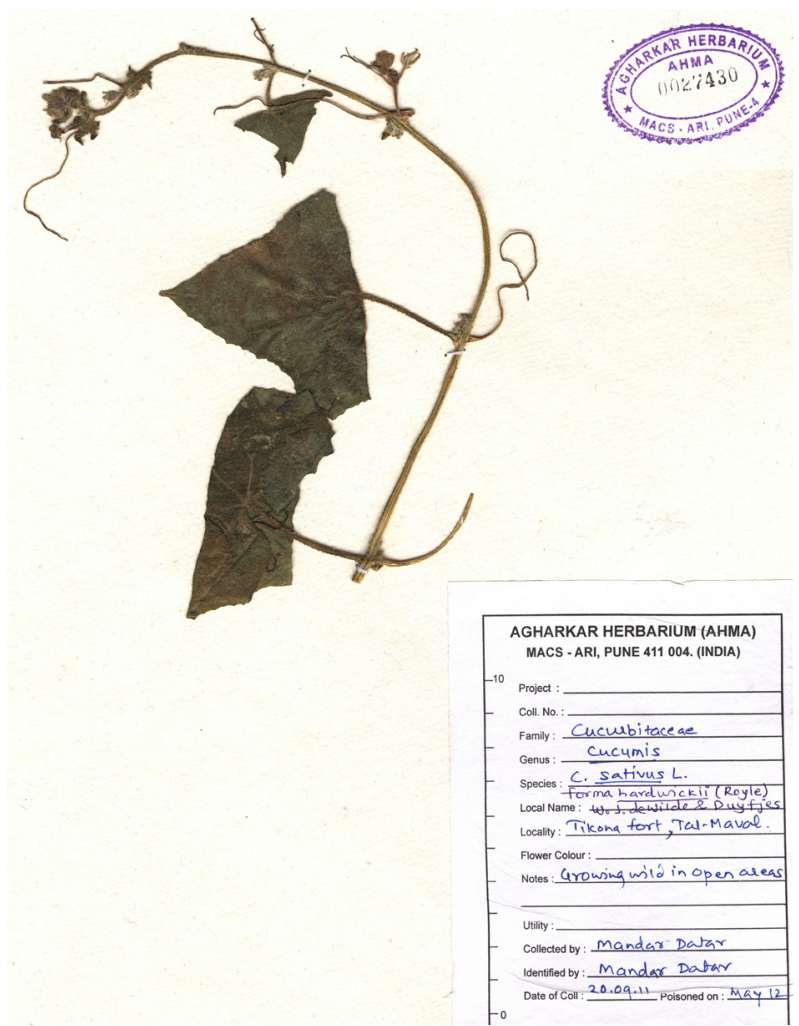

Image 3. Herbarium sheet of Cucumis sativus I. Forma hardwickii (Royle) (27430 AHMA)

of plants, their classification and uses 3rd ed. Cambridge University Press, Cambridge, UK, 235pp.

Matthew, K.M. (1983). The Flora of the Tamilnadu Carnatic: Vol. III. Rapinath Herbarium Tiruchirapally, 642pp.

Pullaiah, T. (1997). Flora of Andhra Pradesh: Vol. I. Scientific publishers, Jodhpur. 409pp.

Rao, K.M. (2001). Cucurbitaceae. In Singh, N.P., P. Lakshminarasimhan, S. Karthikeyan \& P.V. Prasanna (eds.) Flora of Maharashtra State. Dicotyledones. Botanical Survey of India, Calcutta 2: 51-75.

Rao, R.S. (1985). Flora of Goa, Diu, Daman, Dadra \& Nagarhaveli. Vol. 1 Botanical Survey of India, Calcutta, 185pp.

Royle, J.F. (1835). Illustrations of the Botany of the Himalayan Mountains. W.H. Allen \& Co., London, 1: 220; 2: tab. 47: 3.

Saldanha, C.J. (1984). Flora of Karnataka: Vol. I. Oxford and IBH Publishing Co., 308pp.

Sharma, B.D., N.P. Singh \& R. Sundararaghavan (1984). Flora of Karnataka Analysis. Botanical Survey of India, Calcutta, 112pp. 